\title{
Joanna Walewska
}

Uniwersytet im. Mikołaja Kopernika w Toruniu

Katedra Kulturoznawstwa

\section{CO Z JAKOŚCIĄ? O TYM, JAK KRONIKA FILMOWA WRAZ Z "TRYBUNĄ LUDU" WALCZYŁY O DOBRE I TANIE RADIO DLA KAŻDEGO'}

What about quality? On how "Kronika Filmowa" and Trybuna Ludu battled for a good quality radio for everyone

\begin{abstract}
This article discusses the development of the concept of "quality" in the relation to the strategies of Radio-engineering Plants "Diora" in Dzierżoniów and "Kasprzak" plants in Warsaw, which were two main producers of music equipment in the Peoples' Republic of Poland. While taking into account the materials of Polish Newsreels and documents from both the Polish Radio and industrial plants' archives, this analysis aims to show that the concept of "quality" was a subject of various modification and was influenced by such factors as official government's policy and a propaganda, as well as the economical factors and social practices of users.
\end{abstract}

Keywords: quality, stereo, radio-engineering industry, UNITRA

\section{Elizabeth Hi-Fi}

W 1976 roku w sklepie samopomocy chłopskiej działającym przy Zakładach Radiowych Diora w Dzierżoniowie pojawili się filmowcy z Polskiej Kroniki Filmowej. Na półkach jeden z najnowocześniejszych, oferowanych w tym czasie przez Diorę modeli radioodbiorników, czyli „Elizabeth Hi-Fi”, za ladą skonfundowany sprzedawca próbuje zmierzyć się z kolejnymi klientami, którzy oddają uszkodzone odbiorniki. Następnie kamera przenosi się do hal produkcyjnych, a narracja w tle nie

Tekst powstał jako wynik projektu „Radio na uwięzi: przemysł radiowy, instytucje i praktyki użytkowników w PRL”, realizowanego w ramach stażu podoktorskiego w programie „Fuga” Narodowego Centrum Nauki, który odbywał się w Instytucie Historii Nauki PAN w Warszawie, 2016-2017, UMO-2016/20/S/HS2/00070. 
pozostawia wątpliwości - nie jest dobrze, jakość produktów spada na łeb, na szyję, a za wszystko odpowiedzialna jest załoga:

Jesteśmy w hali produkcyjnej Diory w Dzierżoniowie. Schludnie tu, nowocześnie.

- Duże zaangażowanie załogi, tak żeby poprawić jakość, no i oczywiście jest za to większa premia - mówi jedna z pracownic. - Mamy bardziej unowocześnione taśmy i bardziej unowocześnione przyrządy pomiarowe, przy których odbiorniki są bardziej dokładnie zestrajane i reperowane ${ }^{2}$.

Wszystko zatem wydaje się w najlepszym porządku, jednak filmowcy nie dają za wygraną, śledztwo musi toczyć się dalej, więc narrator kontynuuje:

Mimo wszystko coś tu nie gra, najprościej byłoby powiedzieć, że nie grają radia. Niepokoi niska jakość produkcji. Część załogi, jak widać, czeka na bodźce nie tylko finansowe. Liczymy jednak, że wraz z ostatnimi zmianami w Diorze będziemy mieć na rynku tylko sprawne odbiorniki ${ }^{3}$.

W tym czasie kamera wyławia siedzące bezczynnie, znudzone lub przeglądające się w lusterku robotnice oraz flirtujących z nimi mężczyzn, których zachowanie wydaje się potwierdzać, że faktycznie coś tu nie gra. Oko kamery kieruje się na tablice mające za zadanie zmotywować załogę do poprawiania jakości - Zła produkcję musisz naprawić sam. Nie tolerujemy brakorobów! Czy kupiłbyś to, co produkujesz? - w tle słychać muzykę elektroniczną, która podkreśla grozę sytuacji.

Kronika Filmowa gościła już w progach zakładu, pierwsza wizyta zdarzyła się niemalże 30 lat wcześniej, w 1947 roku, kiedy w Bielawie i Dzierżoniowie rodził się dopiero przemysł radiotechniczny. Wtedy podkreślano, że w dolnośląskich zakładach wytwarza się lampy i konstruuje radioodbiorniki dorównujące jakością produkcji światowej, nowoczesne, a przede wszystkim tanie, dostępne dla przeciętnego przedstawiciela klasy robotniczej. W kolejnych latach jej ekipa filmowa pojawiała się też w innych zakładach przemysłowych produkujących sprzęt grający, po to, aby zwracać uwagę na wzloty, ale przede wszystkim na upadki związane z jakością ich produkcji ${ }^{4}$.

\section{Radia z Diory, PKF 76/09B, Kronika 1976, Polska.}

Ibidem.

Pracownicy zapytani o feralną Kronikę Filmową i jakość wyrobów Diory czterdzieści lat później odpowiadali, że materiał filmowy pokazujący ich zakłady w złym świetle był niesprawiedliwy, a jego realizacja była wynikiem polityki oczerniania dzierżoniowskich zakładów przez Kasprzaka lub wręcz, że Kronika „została napuszczona” na ich zakład. Tego rodzaju opinie mogą być traktowane jako przykład „folkloru zakładowego”, choć faktycznie w kilku przypadkach Kasprzak i Diora rywalizowali ze sobą, np. w zakresie produkcji telewizorów kolorowych. 


\section{PRL}

Poświęcone zakładom radiotechnicznym wydania Kroniki Filmowej, o których będzie mowa, z pewnością są współcześnie ważnymi matriałami opisującymi ich funkcjonowanie, jednak obraz, jaki pokazują, jest wykrzywiony, ponieważ nie uwzględnia ówczesnej sytuacji gospodarczej i ekonomicznej. Prawdopodobnie kontekst ten był bardziej zrozumiały w czasie, kiedy poszczególne odcinki Kroniki były oryginalnie wyświetlane, ale nawet wtedy, biorąc pod uwagę propagandę PRL, z pewnością również nie był do końca czytelny. Wydaje się, że radio nie było produktem pierwszej potrzeby, jak odzież czy żywność, ale do pewnego stopnia jakość radioodbiorników oraz ich dostępność na rynku świadczyły o gospodarczej kondycji państwa, dlatego też zakłady radiotechniczne często stawały się tematem i obiektem propagandowych zabiegów Kroniki.

Bazując na przykładach kronik filmowych z okresu od zakończenia wojny do końca lat 70., chciałabym w niniejszym tekście zanalizować to, jak na przestrzeni czasu ewoluowało pojęcie jakości w odniesieniu do sprzętów grających, biorąc pod uwagę specyfikę sytuacji ekonomicznej PRL oraz potrzeby nabywców odbiorników radiowych, patefonów, a w późniejszym okresie magnetofonów czy tunerów. Na podstawie materiałów Kroniki oraz dokumentów z archiwów Zakładów Radiowych Diora chciałabym prześledzić proces, w którym jakość produkcji przestała być synonimem ilości wyprodukowanego sprzętu, a zaczęła odnosić się do jakości jego wykonania oraz do parametrów dźwięku. Prześledzenie relacji pomiędzy pojęciem ilości i jakości może bowiem pozwolić na określenie momentu, w którym wyłoniła się wśród nabywców sprzętu grającego grupa audiofilów. Czy ludzie, którzy przyszli oddać „Elizabeth Hi-Fi” do reklamacji, należą już do tej grupy? Czy faktycznie produkowane przez Diorę sprzęty były tak fatalnej jakości, jak twierdziła Kronika?

Powojenna Polska wydaje mi się dość ciekawym przykładem, ponieważ w żadnym innym kraju przemysł radiotechniczny nie został zupełnie zniszczony do tego stopnia, że jego odbudowa była faktycznie budowaniem od podstaw. W 1945 roku powołany został The Coordinating Committee on Export Controls (COCOM) ${ }^{5}$. Jego celem było ograniczenie eksportu technologii, które mogły mieć zastosowanie militarne. Zakaz ten obejmował również wiele cywilnych technologii, m.in. części odbiorników radiowych czy choćby strategiczne z punktu widzenia odbudowy radiofonii lampy radiowe, w związku z czym Polska prowadziła wymianę handlową na gruncie technologii głównie z krajami zza żelaznej kurtyny ${ }^{6}$. Ponadto 3 stycz-

Y. Yasuhara, The Myth of Free Trade: The Origins of COCOM 1945-1950, „The Japanese Journal of American Studies" 1991, nr 4, s. 127-148.

6 W przedwojennej Polsce we wszystkich działających stacjach nadawczych używano lamp radiowych firmy Marconi, zresztą działające w Warszawie Polskie Zakłady Marconi (PZM) produkowały je i zajmowały się ich konserwacją, aby uniknąć ceł. Po wojnie Polskie Radio zamierzało zawrzeć z firmą Marconi umowę, zgodnie z którą firma miała dostarczać niezbędny sprzęt nadawczy, jak również wybudować fabrykę lamp, jednak do porozumienia nie doszło w związku z wprowadze- 
nia 1946 roku Krajowa Rada Narodowa przyjęła ustawę o nacjonalizacji przemysłu w celu zapewnienia ,planowanego odbudowania gospodarki narodowej” oraz „zapewnienia Państwu suwerenności gospodarczej i podniesienia ogólnego dobrobytu"7. W związku z tym po wojnie wytworzyła się niemalże laboratoryjna sytuacja, w której polski rynek stał się sterowanym centralnie układem zamkniętym, gdzie wszystko należało wybudować od nowa i od podstaw - począwszy od narzędzi poprzez części radiowe aż do gotowych odbiorników. W Polsce pozbawionej zupełnie odbiorników radiowych podczas wojny przez wiele lat marzeniem wielu było posiadanie jakiegokolwiek odbiornika lub choćby głośnika podłączonego do radiowęzła. Sytuacja ta stanowiła punkt wyjścia dla rozwoju przemysłu radiotechnicznego w Polsce.

Przedstawiona w Kronice Filmowej sytuacja w sklepie Samopomocy Chłopskiej w Dzierżoniowie stanowi jednak punkt zwrotny, zwróćmy bowiem uwagę na to, że na materiale uwieczniony został jeden z najnowocześniejszych sprzętów w tym czasie. Cena „Elizabeth Hi-Fi” stanowiła odpowiednik dwóch średnich wynagrodzeń, jednak pomimo to odbiorniki te cieszyły się dużą popularnością i zwykle rozchodziły się na pniu. Wyprodukowana we współpracy z japońską firmą Sanyo „Elizabeth” wyróżniała się na tle innych produkowanych w tym czasie sprzętów audio nowoczesnym wzornictwem oraz dobrymi parametrami dźwięku. Sytuacja gospodarcza kraju w połowie lat 70 . sprawiła, że pracowników zakładów Diora zaczęto wysyłać na targi do krajów zachodnich, gdzie mieli możliwość skonfrontowania sprzętów produkowanych przez Zjednoczenie Przemysłu UNITRA z tymi, jakie dostępne były w krajach kapitalistycznych. Efektem tych wyjazdów było uświadomienie sobie, że parametry techniczne nie są jedynym argumentem przemawiającym za kupnem danego sprzętu, ale że liczą się też nowoczesny design, cena oraz marka.

\section{Syłuacja po wojnie}

W czasie wojny zniszczony został przemysł radiotechniczny, ocalało zaledwie kilka zakładów radiotechnicznych w centralnej Polsce oraz poniemieckie zakłady na Dolnym Śląsku, które począwszy od lutego 1945 roku, były stopniowo przejmowane i uruchamiane przez Polskie Radio ${ }^{8}$. Ponieważ słuchanie radia było zabronione w czasie okupacji, większość odbiorników radiowych została zarekwirowana, a te, które udało się Polakom ukryć, często ze względu na złe warunki przechowywania

niem COCOM-u, w rezultacie fabrykę przy ulicy Karolkowej wybudował Philips. Zanim fabryka powstała, lampy radiowe sprowadzane były z Czechosłowacji z firmy Radioslavia, która przed wojną była podobnie jak PZM firmą zależną od Marconiego. Jeśli chodzi o odbiorniki radiowe, umowę podpisano ze szwedzką firmą Aga-Baltic, o czym będzie mowa w dalszej części tekstu.

7 Ustawa z dn. 3 stycznia 1946 r. o przejęciu na własność Państwa podstawowych gałęzi gospodarki narodowej, Dziennik Ustaw Rzeczpospolitej Polskiej z 1946 r., nr 3, poz. 17.

8 Zob. J. Walewska, M. Białecki, Zakłady „IKA” jako przykład nacjonalizacji przemystu radiotechnicznego po wojnie (z Maciejem Białeckim), w: Hi-tech za żelazna kurtyną. Elektronika, komputery i systemy sterowania w PRL, red. M. Sikora, IPN, Katowice 2017, s. 493-518. 
nie dotrwały do końca wojny w stanie, który pozwalałby na ich użytkowanie. Dekret znoszący zakaz słuchania radia został wydany dopiero w czerwcu 1946 roku i jak się ocenia, na rynku było w tym czasie około 50 tysięcy odbiorników, zwykle poniemieckich, które udało się ludziom wyszabrować z opuszczanych przez Niemców terenów lub które przetrwały w rękach folksdojczów ${ }^{9}$. Spora część odbiorników radiowych znalazła się też w tym czasie w gestii Polskiego Radia, które odbierało je w okresie, kiedy zakaz słuchania radia nie został jeszcze zniesiony, pod pozorem, że stanowią one mienie pozostawione przez Niemców. Właścicielom radioaparatów odbierano sprzęt za pokwitowaniem, jednak nie obiecywano, że kiedykolwiek zostanie on zwrócony $^{10}$. Innym źródłem pozyskiwania odbiorników były pozostawione przez Niemców składy odbiorników zarekwirowanych Polakom na początku wojny. Niemalże wszystkie pozyskane w ten sposób odbiorniki były jednak bardzo złej jakości lub całkowicie niesprawne, zwykle ze względu na potłuczone lampy, których nie można było zastąpić nowymi. Ich produkcja ruszyła w Bielawie dopiero w 1946 roku, a cały proces był niezwykle mozolny, ponieważ brakowało surowców, maszyn oraz ludzi znających technologię ich wytwarzania. W kronice z 1946 roku mowa jest o tym, że Polskie Radio w Łodzi zorganizowało akcję reperacji 52 sztuk odbiorników radiowych, które zostały przekazane jako nagrody rzeczowe dla chłopów, którzy najlepiej wywiązali się z obowiązku przekazania świadczeń rzeczowych ${ }^{11}$. Następnie kamera Kroniki przenosi się do wiejskiej chaty Tomasza Dobrowolskiego z Nowego Miasta nad Pilicą, który wraz z żoną włącza właśnie odbiornik radiowy. Scena uchwycona przez ekipę Kroniki jest bardzo znacząca, odbiornik postawiony zostaje bowiem na szafce przykrytej białą serwetą obok figurki Matki Boskiej, w tzw. świętym kącie, który w przestrzeni wiejskiej chaty wyznaczał przestrzeń sacrum. Ceniono nawet odbiorniki pośledniej jakości, ponieważ umożliwiały odbiór audycji, a tym samym kontakt ze światem.

Ilość dostępnych odbiorników w tym czasie była kroplą w morzu potrzeb, dlatego wyprodukowanie popularnych odbiorników, obok uruchomienia zdewastowanych stacji radiowych, było jednym z głównych zadań stojących przed Polskim Radiem. Od 1947 roku ruszyła w dzierżoniowskich zakładach produkcja odbiorników AGA, na licencji szwedzkiej firmy AGA-Baltic, których zamierzano wyprodukować 30 ty-

Zob. Sprawozdanie Inspektora Szmidta Stefana z powtórnie przeprowadzonej wizytacji Komisji Likwidacyjnej Wytwórni Radiosprzętu przy Rozgłośni P.R. w Katowicach w czasie 30.VI-15.V. 1947, ODiZP 4/3/1 oraz wypowiedź Edwarda Odorkiewicza, Dyrektora Rozgłośni Śląskiej w Katowicach podczas Zjazdu Delegatów Dyrekcji Okręgowych Polskiego Radia w Szklarskiej Porębie, 17-19 lipiec 1945, ODiZP 14/3/2, k. 97. Odorkiewicz szacował, że na terenie Górnego Śląska zachowało się ok. 35 tysięcy odbiorników, jednak do tej liczby należy doliczyć aparaty radiowe produkcji niemieckiej, które udało się odzyskać Polskiemu Radiu na terenie Dolnego Śląska (ok. 2 tysięcy sztuk), a także sprzęt, który znajdował się w prywatnych rękach.

10 Zob. wypowiedź Odorkiewicza podczas Zjazdu Delegatów Dyrekcji Okręgowych Polskiego Radia w Szklarskiej Porębie, 17-19 lipiec 1945, ODiZP 14/3/2, k. 97.

11 Radioodbiorniki jako nagroda dla chtopów, którzy odstawili świadczenia rzeczowe dla państwa, PKF 46/10. Kronika, 1946. 
sięcy sztuk w ciągu trzech lat ${ }^{12}$. Odbiorniki te występowały w dwóch wersjach: jedna $\mathrm{z}$ nich - abonencka, przeznaczona była dla indywidualnych odbiorców, natomiast druga wyprodukowana była z myślą o radiowęzłach, zatem można było do niej podpiąć dodatkowe głośniki, wzmacniacz lub patefon ${ }^{13}$.

W 1950 roku produkcję odbiorników AGA przejęły częściowo powstałe rok wcześniej Zakłady Kasprzaka, a asortyment odbiorników poszerzył się również o pierwszy odbiornik produkcji polskiej skonstruowany przez inż. Wilhelma Rotkiewicza, czyli o sławnego Pioniera ${ }^{14}$. Pionier miał być odbiornikiem popularnym, co oznaczało, że musiał być stosunkowo tani, a w związku z różnicami w poziomie elektryfikacji kraju występował w kilku wersjach, m.in. na prąd zmienny, stały oraz na baterie. „Zielone oko”, jak nazywano często radio AGA, było jednak przez kolejne lata obiektem pożądania, m.in. ze względu na to, że Pionier miał skrócony zakres fal krótkich, po to, aby nie można było na nim słuchać zakazanych stacji zachodnich ${ }^{15}$.

Zarówno AGA, jak również Pionier stały się po wojnie odbiornikami kultowymi, po prostu dlatego, że można je było „zdobyć”, a możliwość słuchania radia dla wielu ludzi miała znaczenie symboliczne, przypieczętowywała zakończenie wojny. W liście do redakcji PR nadesłanym z Ostrowa Wielkopolskiego przez Mariana Trachimowicza wspomniane zostają obydwa „zdobyczne” odbiorniki radiowe:

A potem okupacja i słuchanie zakazanych audycji z odbiornika zainstalowanego u p. Bochenków pod łóżkiem. Dziwny to był zaiste widok - cztery, pieć osób z głowami pod łóżkiem. Wojsko i pierwsza audycja z Lublina... Pierwsza „toczka” po wojnie, a następnie już w 1950 roku w nowo założonej, własnej rodzinie poważna i niezwykła inwestycja: zakup (po kumotersku) odbiornika „Aga” z magicznym okiem, na częściach szwedzkich (pracuje do dnia dzisiejszego) i słuchanie, słuchanie... W tym samym roku w konkursie „Literatura pięciolecia PRL” wygrywam... „Pioniera" 16 .

W kolejnych latach konstrukcja Pioniera była modernizowana, a sam odbiornik był dostępny na rynku przez ponad 20 lat, choć występował pod różnymi nazwami. W 1968 roku na łamach gazety zakładowej Tadeusz Wszoła z nostalgią obwieścił zakończenie produkcji radioodbiornika „Promyk” opartego na niezawodnym „Pionierze":

12 Protokót z konferencji odbytej w Centralnym Urzędzie Planowania w dniu 12 marca 1946 roku w sprawie wytycznych dotyczacych potrzeb $w$ zakresie sprzętu telekomunikacyjnego i radiotechnicznego, 20, k. 38. Archiwum Państwowe we Wrocławiu / o. Kamieniec Ząbkowicki [APWK], Zakłady Radiowe „Diora” w Dzierżoniowie-596 [596]/20, k. 38.

13 Zob. karta katalogowa odbiornika Aga nr 00634 na stronie Old Radio, http://www.oldradio.pl/karta. php?634.

14 Sprawy ogólne i planów, APWK, 596/21, k. 81-84.

15 Ibidem.

16 List M. Trachimowicza, Wspomnienia stuchaczy dotyczace historii radia przesłane w zwiazku z ogłoszona w prasie i radiu ,Radiowa Ankieta Wspomnien”” z okazji 50-lecia PR, Spuścizna Macieja Kwiatkowskiego, Archiwum Polskiego Radia, MK-A/408. 
W pierwszych dniach stycznia br. „Promyk” zakończył swą karierę. Do końca okazał się nieprześcigniony. Stąd decyzja o zaniechaniu produkcji tych odbiorników może się wydać niesłuszna. Wydaje się bowiem, że ostatnie słowo powinno należeć do klienta. Być może w grę weszły też inne względy. Nie mamy wpływu na tego rodzaju werdykty ${ }^{17}$.

W 1950 roku podczas V Zjazdu PZPR zadecydowano, że produkcja radioodbiorników powinna wzrosnąć tak, aby w 1955 roku osiągnąć liczbę 300 tysięcy, z czego 120 tysięcy miała wyprodukować Diora, a pozostałe nowo otwarte zakłady T-3 w Warszawie (czyli Kasprzak). Pomimo tego, że realizacja wyznaczonych odgórnie norm była i tak ambitnym planem, dzierżoniowskie zakłady podjęły się wyprodukowania 255 tysięcy odbiorników, co stanowiło 75\% produkcji krajowej, a ostatecznie do końca drugiej pięciolatki były w stanie wyprodukować 353 tysiące odbiorników radiowych ${ }^{18}$. Pomimo przyśpieszenia tempa produkcji w okresie pierwszego planu 5-letniego odbiornik radiowy był wciąż jednak rarytasem, drogim i niedostępnym. Choć przez cały okres lat 50. mowa była o jakości produkcji, za co zakłady przemysłowe regularnie łajane były poprzez oficjalne kanały propagandy, czyli na łamach prasy oraz na antenie Polskiego Radia, to jednym z głównych zagadnień była mimo wszystko wydajność produkcji. Na łamach gazet zakładowych szerzył się kult racjonalizatorstwa: organizowano m.in. konkursy, w których autorzy najlepszych wynalazków lub ulepszeń wygrywali nagrody albo premie, jednak podstawowymi kryteriami była oszczędność materiałów i narzędzi oraz podniesienie ilości produkcji. Po tym jak powstały Zakłady Kasprzaka (T-3) oraz Fonica (T-4) w Lodzi rynek powoli nasycał się odbiornikami oraz sprzętem do odtwarzania muzyki ${ }^{19}$. Były one niezbyt wysokiej jakości, w związku z czym na początku lat 60. sprzedaż znacząco spadła, a wyprodukowane towary zaczęły się piętrzyć w magazynach. Utrzymana w konwencji skeczu kabaretowego kronika Warszawskie salony miała stanowić zachętę do ich kupna. Jedno z ujęć, przedstawiające tańczącą wdzięcznie parę, nakręcone zostało w sklepie firmowym i towarzyszy mu komentarz: „Salon Kasprzaka, radia na każdą stopę życiową - od 900 do 5 tysięcy złotych"20. Jest to sygnał wysłany do widzów, że być może nie mieszkają na salonach, ale drzwi salonu z odbiornikami radiowymi stoją przed nimi otworem.

17 T. Wszoła, Żegnajcie „,promyki”, „Diora. Gazeta Samorządu Robotniczego”, styczeń 1968.

18 DIO-RA-DIO. Zaktady Radiowe Unitra „Diora” w Dzierżoniowie, Wydawnictwo Przemysłu Maszynowego „WEMA”, Warszawa 1978, s. 3-33.

19 Zakłady radiotechniczne pojawiają się w dwóch wydaniach Kroniki Filmowej w tym okresie: w odcinku pt. Jeszcze o Targach, PKF 58/25A, Kronika 1958 mowa jest o odbiornikach radiowych z Diory i Kasprzaka prezentowanych na Targach Poznańskich, natomiast w odcinku Przed III Zjazdem zobowiazania zakładów pracy, PKF 59/03A, Kronika 1959 mowa jest o przyśpieszeniu produkcji w Kasprzaku, który zadeklarował wypuszczenie na rynek popularnego odbiornika radiowego „Melodia" oraz odbiornika radiowego z patefonem.

Warszawskie salony, PKF 62/01A, Kronika 1961. 


\section{"Bez reklamacii"}

Napięta sytuacja polityczna w kraju (plotki o wymianie pieniędzy: wrzesień 1961, wrzesień i październik 1963, styczeń 1968, październik i listopad 1969) oraz na świecie (wzniesienie muru berlińskiego 1961, kryzys kubański 1962, wojna na Bliskim Wschodzie 1967 oraz interwencja w Czechosłowacji w sierpniu 1968 roku) spowodowały wzrost niepokojów społecznych, który przejawiał się wykupywaniem ze sklepów artykułów pierwszej potrzeby ${ }^{21}$. Jednak kryzys z przełomu lat 1966-1967 spowodował również wzrost zapotrzebowania na środki tezauryzacyjne, takie jak dewizy czy złote sztabki i monety. Na początku 1968 roku czarnorynkowy kurs dolara był najwyższy od 1957 roku, rozpoczął się również szturm na sklepy mające w swojej ofercie towary luksusowe, takie jak sprzęt radiotechniczny i telewizory, jednak na rynku brakowało wciąż odbiorników radiowych i telewizyjnych o podwyższonej jakości.

W 1966 roku ekipa Kroniki Filmowej pojawiła się tym razem w warszawskich Zakładach Kasprzaka, gdzie nakręciła materiał filmowy zatytułowany Na przykład „, Kasprzak”, w którym podkreślano złą jakość wyrobów.

Dlaczego tak często odbiornik z Zakładów Kasprzaka psuje się tuż po nabyciu? Główną winę ponoszą kooperanci, którzy dostarczają 95 procent części montażowych, przeważnie niskiej jakości. 25 procent lamp radiowych nie nadaje się do użytku. Nawet tak drobne elementy jak kondensatory są przyczyną poważnych uszkodzeń. Ale bądźmy szczerzy, w samej fabryce nie wszystko gra. O polepszeniu jakości cyny musiał zadecydować dopiero minister. Lutowane automatycznie końcówki trzeba poprawiać ręcznie. A potem te nieszczęsne podzespoły od kooperantów. Pracownicy Kasprzaka mówią: „No cóż, my składamy do kupy to, co inni nam dostarczą, bo nie ma zapasów". Na taśmie aparat zatrzymuje się na dwie minuty, kto nie zdąży, odkłada na podłogę do poprawek. Wstrząsarka kontrolna - rozleci się czy wytrzyma? Czasem rozlatuje się dopiero u nas w domu. Koszty napraw gwarancyjnych wliczone są do ceny odbiornika, za wszystko płaci więc klient ${ }^{22}$.

Wizyta filmowców była konsekwencją rozpętanej w styczniu 1965 roku przez „Trybunę Ludu” kampanii na rzecz poprawy jakości wyrobów przemysłowych, której redakcja ogłosiła ankietę zatytułowaną „Bez reklamacji”. Czytelnicy gazety zaproszeni zostali do odpowiedzi na trzy pytania: 1. Czy i jak często spotykają się z wyrobami złej jakości?; 2. Jakie są główne przyczyny tego, że wyroby przemysłu polskiego odbiegają od standardów światowych?; 3. Jakie kroki powinno się przedsięwziąć, aby zmienić ten stan rzeczy? Do redakcji wpłynęło 510 odpowiedzi na ankietę i jak piszą autorzy opracowania jej wyników w książce pod tym samym tytułem:

${ }^{21}$ Zasoby pieniężne ludności a równowaga pieniężno-rynkowa, kwiecień 1970, AAN, KC PZPR, XI/775, k. 25-26.

22 Na przykład „Kasprzak”, PKF 65/14B, Kronika 1965. 
Charakteryzowały się śmiałością w stawianiu trudnych nieraz i kontrowersyjnych zagadnień oraz znaczną dozą krytycyzmu. (...) Sprawy ujmowano na ogół kompleksowo, zwracając przy tym uwagę na rozmaite czynniki wpływające na jakość produkcji23.

Wyniki ankiety publikowano na łamach dziennika wraz z wypowiedziami członków rządu, były one również szeroko dyskutowane w prasie, radiu, telewizji oraz Kronice Filmowej, gdzie podkreślano wagę problemów związanych z zarządzaniem, problemy kontroli technicznej, złej jakości półprodukty, nieregularne dostawy, złe wyszkolenie pracowników etc. Oficjalną reakcją władz na zawarte w odpowiedziach na ankietę uwagi miały być uchwały IV Plenum KC PZPR, które przewidywały „stopniowe zmiany zarządzania gospodarką”, których „,kierunek jest w zasadniczych liniach zgodny z tezami wysuwanymi przez wielu uczestników ankiety”. Jednak jak we wstępie do książkowego opracowania jej wyników zaznaczają autorzy Leon Guz, Mirosław Kowalewski, Andrzej Witkowski i Andrzej Żmuda - na progu nowej pięciolatki, zwanej „pięciolatką jakości”, nie da się rozwiązać problemu jakości produkcji jednym aktem normatywnym ${ }^{24}$. Przedrukowane w Bez reklamacji wypowiedzi krążyły głównie wokół tematu norm, jednak w przeprowadzonej ankiecie pojęcie to występuje w dwóch znaczeniach. Pierwsze z nich dotyczy pojęcia normy odnoszącego się do podstawowego dotychczas miernika wyników osiąganych przez zakład, czyli ilości, natomiast drugie znaczenie normy odnosi się bezpośrednio do jakości wytwarzanych produktów. W rozdziale Nowoczesność $i$ wysoka jakość - naczelnym zadaniem całej gospodarki Bolesław Jaszczuk pisze, że przez ostatnie dwie dekady zwracano uwagę przede wszystkim na ,ilościowe zaspokojenie społecznych potrzeb", jednak nie przykładano odpowiedniej wagi do poprawy trwałości, niezawodności, starannego wykończenia oraz poprawy estetyki wyrobów przemysłowych ${ }^{25}$.

Właściwie wśród ankietowanych panował pełen konsensus, że zasadniczo nie ma sprzeczności pomiędzy ilością a jakością produkcji, jednak wskazywali oni równie dobitnie na fakt, że w sterowanej centralnej gospodarce tego typu z pozoru łatwy do osiągnięcia balans był $\mathrm{w}$ istocie stanem nieosiągalnym.

W kolejnych latach dyskusja na temat jakości produkowanych wyrobów znalazła odzwierciedlenie w artykułach publikowanych w gazecie zakładowej wydawanej przez Zakłady Radiowe Diora. Jest to jest symptomatyczne, ponieważ w drugiej połowie lat 60. po raz pierwszy jakość i estetyka wykonania oraz design zaczęły odgrywać pierwszorzędną rolę, co było m.in. efektem przeprowadzonej przez „Trybunę" ankiety. Jaszczuk pisał m.in., że na obecnym stopniu rozwoju polskiej ekonomii nie można już koncentrować się wyłącznie na ilościowym zaspokajaniu potrzeb, ale należy dogłębnie przemyśleć problematykę nowoczesności i jakości produkcji,

${ }^{23}$ L. Guz i in., Bez reklamacji. Ankieta „Trybuny Ludu” na temat jakości, Warszawa 1966, s. 5-6.

24 Ibidem.

25 Ibidem, s. 69. 
pod kątem rozwijania rynku wewnętrznego, jak również rozwijania „ofensywy eksportowej"26.

Wypowiadając się na temat normalizacji, wielu ankietowanych podkreślało, że największym mankamentem wyznaczanych dla zakładów przemysłowych norm jest ich statyczność, są za mało wrażliwe na zmieniające się realia oraz nie nadążają za postępem światowym, w związku z czym nie zaspokajają potrzeb klientów ${ }^{27}$. Chciałabym się przez chwilę zatrzymać na problemie konfrontacji norm z potrzebami klientów, ponieważ dyskusja na temat wyglądu radioodbiorników diorowskich przybierała momentami dość zaskakujące kierunki.

W listopadowym wydaniu gazety zakładowej z 1967 roku Tadeusz Wszoła w artykule zatytułowanym Wzornictwo - problem zasadniczy podejmuje się próby odpowiedzi na pytanie o to, dlaczego wygląd produkowanych przez Diorę odbiorników radiowych i telewizyjnych ma tak duże znaczenie. Odpowiada bez wahania, że „spełniają one funkcję dekoracyjną w mieszkaniu i muszą się kupującemu podobać" ${ }^{28}$. Wszoła pisze, że choć Diora dysponuje pracownią wzornictwa działającą przy biurze konstrukcyjnym, to i tak zadanie zaprojektowania odbiorników, które będą się cieszyć popularnością, jest trudne, ponieważ w kraju nie prowadzi się badań pozwalających określić grupę przyszłych nabywców. W związku z tym pracujący w zakładach, wykształceni w szkołach artystycznych plastycy nie powinni kierować się własnym gustem, ponieważ produkcja Diory przeznaczona dla rodzimego odbiorcy powinna się dopasować do gustów „ludzi, którzy w większości mają co najwyżej średnie wykształcenie, nie studiowali na ASP, lubują się w »ciężkich«, na wysoki połysk meblach, na ścianie zawieszają wyszywane jelenie i idąc do sklepu, szukają odbiorników, które by do ich mieszkania "pasowały «"29.

Zdaniem Wszoły, przykładem odbiornika, którego nie można uznać za nowoczesny, choć produkowano go w ilości kilkudziesięciu tysięcy sztuk, był „Menuet”, w którym wymieniono wnętrze, pozostawiając jednak tę samą „ciężką”, drewnianą skrzynkę, ponieważ - jak pisze - radio to cieszy się większym powodzeniem wśród klientów niż zdecydowanie nowocześniejsza seria „Bostonów”, „Kankanów” czy „Saraband”. Proponuje zatem, żeby większość sprzętu produkować w starszym typie obudowy, a aparaty w nowoczesnej szacie wypuszczać na rynek w małych seriach, bowiem tylko taka strategia pozwoli Diorze na zaspokojenie potrzeb klientów oraz na utrzymanie produkcji na odpowiednim poziomie. Należy zwrócić uwagę, że na początku 1968 roku nowy dyrektor zakładu inż. Jędryczka w taki sposób opisywał cele, jakie stały przed załogą zakładu:

26 Ibidem.

27 Ibidem.

${ }_{28}$ T. Wszoła, Wzornictwo - problem zasadniczy, „Diora. Gazeta Samorządu Robotniczego”, listopad 1967.

29 Ibidem. 
W zakresie eksportu zadania na rok 1968 są wyższe niż w roku ubiegłym o blisko cztery razy. Od załóg realizujących te zadania będzie to wymagało podniesienia na wysoki poziom kultury wykonawczej, gdyż wyrób musi się za granicą bronić sam, swoją jakością, niezawodnością i estetyką ${ }^{30}$.

Jednak wydaje się, że na tym etapie nie wiedziano jeszcze, jak zrealizować te cele. Wszoła podsumowuje swoje rozważania na temat designu w dość zaskakujący sposób, twierdzi bowiem, że należy zwrócić uwagę na szatę wyrobów (żeby nie była zbyt szokująco nowoczesna), ale jeśli chodzi o wnętrze, to „może ono być nawet supernowoczesne", ponieważ większość kupujących przywiązuje do niego mniejszą wagę, co ,jest zrozumiałe, gdyż nigdy nie zetknęli się z radiotechniką" ${ }^{31}$. Z wypowiedzi autora wynika, że pierwszorzędnym problemem była jakość produkowanego sprzętu, która nadal rozumiana była jako niezawodność, trwałość lub ewentualnie tradycyjny wygląd, jednak w jego rozważaniach nieobecna jest w ogóle problematyka jakości samego dźwięku.

\section{W jakości stereo}

Problematyka jakości dźwięku pojawia się w literaturze przedmiotowej już w latach 60., jednak bardziej interesujące niż literatura fachowa wydają się opracowania popularne na ten temat, ponieważ wskazują one na proces społecznego kształtowania się słuchu muzycznego. Przykładem książki tego typu jest Człowiek i dźwięk. O kulturze słuchania radia, napisana przez Kazimierza Dobrzyńskiego. Jej autor stawia sobie za cel przeciwdziałanie - jak pisze - ,złej tradycji nieustannego słuchania radia” oraz „,brakowi kultury słuchania radia”, objawiającemu się przede wszystkim „trudnościami w przyjmowaniu właściwej postawy psychicznej dla odebrania przeżycia estetycznego"32. Dobrzyński zauważa, że choć nadal radio jest dominującym medium, to pojawiają się na rynku inne sprzęty audio umożliwiające słuchanie muzyki, dlatego utożsamia kulturę słuchania radia z ,kulturą słuchania dźwięku zakonserwowanego środkami fonograficznymi” i „odtwarzaniem go w sposób niezawodny i dający satysfakcję estetyczną"33. Choć zwraca on uwagę na to, że przystępując do słuchania radia z nadzieją na uzyskanie przeżycia estetycznego, należy zwrócić szczególną uwagę na stan techniczny radioodbiornika (być może wymaga on specjalistycznego serwisu w ZURT), podkreśla też, że nie bez znaczenia jest to, czy ów odbiornik wyposażony jest w pasmo UKF, czy ma jeden czy dwa głośniki, czy mają one kształt okrągły czy prostokątny i czy można w nim korygować pasma wysokich i niskich częstotliwości ${ }^{34}$. Autor książki niewiele miejsca

30 Mówi dyrektor „Diory” inż. Z. Jędryczka, „Diora. Gazeta Samorządu Robotniczego”, styczeń 1968.

31 T. Wszoła, Wzornictwo - problem zasadniczy, op. cit.

32 K. Dobrzyński, Człowiek i dźwięk. O kulturze stuchania radia, Warszawa 1973, s. 11-13.

33 Ibidem, s. 53, 55.

34 Ibidem, s. 121. 
poświęca problematyce dźwięku stereofonicznego, na jednej z ilustracji pokazana jest kobieta w nowoczesnym mieszkaniu ery Gierka zmieniająca płytę w gramofonie, a podpis pod zdjęciem głosi: „Nowoczesny domowy sprzęt odtwarzający płyty stereofoniczne" ${ }^{\prime 35}$. Rysunek ma znaczenie poglądowe, bowiem, jak pisze, , jeśli posiadamy jeden z pierwszych w naszym kraju importowanych radioodbiorników stereofonicznych lub posiadamy gramofon stereofoniczny ${ }^{36}$, to z dołączonych do nich instrukcji wiemy, że miejsce, w którym siedzimy podczas audycji stereofonicznej, jest niezwykle ważne" 37 .

Warto też zwrócić uwagę na okładkę książki, na której tylnym skrzydełku znajduje się przeznaczony do wycięcia krążek stroboskopowy, za pomocą którego można zmierzyć prawidłowość obrotów talerza adaptera. O ile radiowe testy stereo zakładały, że radioamator jest w stanie usłyszeć to, co dzieje się z dźwiękiem w lewym i prawym kanale, o tyle w tym przypadku następuje swoista translacja procesu słyszenia na proces widzenia, bowiem:

Po uruchomieniu talerza adapterowego powstaje efekt optyczny nakładania się na siebie kresek wydrukowanych na stroboskopie (oświetlanych lampą elektryczną zapalającą się i gasnącą w rytmie 50 razy na sekundę. Jeśli adapter ma prawidłowe obroty $331 / 3$ ), zobaczymy efekt zatrzymania się kresek na stroboskopie w kręgu środkowym. (...) Prawidłowość obrotów talerza zapewnia odtwarzanie muzyki we właściwej tonacji i odpowiedniej jakości pasma częstotliwości is.

Można zatem powiedzieć, że choć Dobrzyński dostrzegał zainteresowanie kwestiami jakości dźwięku, to nie miał zbyt dobrego zdania o słuchu muzycznym ówczesnych Polaków.

Polskie Radio rozpoczęło regularne nadawanie audycji w jakości stereo dopiero w latach 70.: przede wszystkim program II zasłynął audycjami muzycznymi, które poprzedzone były testami stereofonicznymi, jednak reszta programu nadawana była w mono. Pierwszym polskim stereofonicznym odbiornikiem radiowym klasy Hi-Fi była wieża lampowa DSL-201, nad którą prace trwały już w 1969 roku, a produkcję uruchomiono w roku następnym. Jednak zanim prezentowany model odbiornika „przetarl” ścieżkę dla rozwoju stereofonii w Polsce, minęło kilka lat. „Meluzyna”, czyli pełnotranzystorowy zestaw tunera ze wzmacniaczem, nie od razu znalazła swoich amatorów i raczej budziła zdziwienie: co to za radio, skoro nie ma głośników?

Podobnie jak w przypadku „Pioniera”, który spopularyzował słuchanie radia, potrzebny był na rynku stosunkowo tani odbiornik stereo, aby większa ilość słuchaczy

35 Ibidem, s. 124.

36 Pomimo tego, że w latach 60. pojawiają się w Polsce pierwsze sprzęty stereo, np. radio lampowe z Diory „Carmen Stereo” oraz gramofon „Dueton” z Foniki, standardem był wciąż dźwięk monofoniczny i jedynie ewidentne odstępstwa od normy, takie jak zbyt wolne przewijanie lub trzaski, były odnotowywane przez nabywców.

37 K. Dobrzyński, Człowiek i dźwięk..., op. cit., s. 124.

38 Ibidem, wewnętrzne skrzydełko okładki książki. 
miała szansę przywyknąć do nowego standardu dźwięku. Pionierską rolę w tym zakresie miał odegrać odbiornik „Amator-Stereo”. Pomysł i projekt pojawiły się dość wcześnie, jednak jak zwykle diabeł tkwił w szczegółach, problemem technicznym okazało się niedostarczenie na czas potencjometrów stereofonicznych z wyłącznikiem sieciowym przez ,Telpod”.

Chciałabym w tym miejscu przedstawić kulisy, jakie towarzyszyły wypuszczeniu na rynek „Amatora-stereo”, opisane przez Chudzik na łamach gazety zakładowej:

Początkowo było dużo zapału. (...) Żeby jednak przystąpić do pracy, trzeba było znaleźć motywację działania. Wtedy, w 1972 roku, odbiorniki stereofoniczne „Diory” pojawiły się już na rynku - nie miały jednak zbytniego popytu. Ludzie nie za bardzo wiedzieli, co to jest stereofonia, a radia były drogie. Tylko przez kilka godzin tygodniowo rozgłośnie Polskiego Radia nadawały program stereofoniczny.

Zetemesowcy z „Diory” rozumowali tak: są radia stereo, ale nie ma przyzwoitej ilości godzin programu. Trzeba więc zmusić rozgłośnie do nadawania programów stereo przez nasycenie rynku popularnymi i tanimi odbiornikami stereofonicznymi. Nie było inicjatywy ze strony Polskiego Radia, musiała więc wyjść od przemysłu. Pamiętano jeszcze o jednym: - kto raz posłucha stereofonii, ten nie zechce już słuchać muzyki mono. Tani „Jubilat-stereo” będzie więc tym odbiornikiem, który przekona radiosłuchaczy do stereofonii i stworzy popyt na radia stereo wysokiej klasy ${ }^{39}$.

Krzyżanowski, jeden z młodych konstruktorów należących do zakładowego koła ZMS, którego członkowie podjęli się zadania wybudowania odbiornika, powiedział:

(...) ta krytyka w prasie. To zniechęca. Jeżeli popularny odbiornik stereofoniczny kosztuje dzisiaj 7 tysięcy zł, trudno jest wymyślić aparat podobnej klasy za około 2,5 tysiąca zł. A nam chodziło o odbiornik tani. Chcieliśmy zrobić aparat, który spełniając podstawowe wymogi stereofonii, byłby dostępny dla każdej niemal kieszeni. Mam wrażenie, że nam się to udało. Chcemy, by ten aparat rozpowszechnił stereofonię w Polsce, jak „mały fiat” motoryzację. To było podstawowym naszym celem i chcemy, aby naszą pracę tak właśnie traktowano ${ }^{40}$.

Coś jednak było na rzeczy, ponieważ w tym samym numerze gazety opublikowane zostało wezwanie pracowników Foniki do tego, aby opracowali projekt gramofonu stereo oraz informacja o tym, że UNITRA zaprzestaje produkcji gramofonów połączonych z radiem w związku z brakiem zainteresowania tego typu sprzętem ze strony klientów, którzy domagali się w zamian większej ilości Amatorów na rynku ${ }^{41}$.

W jaki sposób doszło do tego, że dźwięk monofoniczny, który do tej pory był normą, nagle okazał się niewystarczający i nabywcy zapragnęli, aby polskie zakłady zaczęły produkować sprzęt stereofoniczny? W grudniu 1970 roku pierwszym sekretarzem KC PZPR wybrany został Edward Gierek, a zaciągnięte przez niego kredyty spowodowały przyśpieszenie gospodarcze, wzrost płac realnych, a co za tym idzie, wzmożoną konsumpcję. W 1971 roku zmalała liczba skarg na zaopatrzenie sklepów,

39 Rynek czeka na „Jubilata-Stereo”, „Diora. Gazeta Samorządu Robotniczego”, 22 lipca 1974.

40 Ibidem.

${ }^{41}$ Czy zmierzch radia z gramofonem?, „Diora. Gazeta Samorządu Robotniczego”, 22 lipca 1974. 
w tym w towary luksusowe, takie jak np. samochody, telewizory (również kolorowe) oraz wyższej jakości sprzęt radiotechniczny ${ }^{42}$.

Świadectwem zmiany była przeprowadzona w styczniu 1974 roku przez redakcje Polskiego Radia i „Trybuny Ludu” ankieta, mająca za zadanie wysondować preferencje słuchaczy radia odnośnie do radioodbiorników, które chcieliby posiadać. Po konsultacjach ze zjednoczeniem UNITRA obydwie redakcje postanowiły zapytać swoich słuchaczy i czytelników, jakie jest ich wymarzone radio. Zgłoszone propozycje, które spływały z kraju i ze świata, miały stanowić asumpt do skonstruowania „wymarzonego radia dla każdego”. Największą niespodzianką plebiscytu był postulat, że powinien to być odbiornik stereofoniczny stołowy lub przenośny, ale z głośnikami w oddzielnych obudowach, za czym opowiedziała się niemalże połowa respondentów, natomiast przeszło jedna trzecia chciała odbiornika stereofonicznego z wbudowanymi głośnikami. Poza tym odbiornik miał być pełnozakresowy, niezawodny, ładny i niedrogi, zbliżony parametrami do urządzeń klasy Hi-Fi; powinien mieć możliwość współpracy z gramofonem, magnetofonem i umożliwiać dołączenie słuchawek.

W związku z ankietą ekipa Kroniki Filmowej ponownie pojawiła się w Kasprzaku, który już tradycyjnie został zbesztany za złą jakość produkowanych tam urządzeń ${ }^{43}$. W zrealizowanym materiale słychać z offu głos sprzedawcy opowiadającego o magnetofonach kasetowych MK-125, które bardzo często nie działają już w sklepie, a część z nich psuje się w domu klienta w okresie od trzech do 10 dni obowiązywania gwarancji. Problemem jest głośna praca silnika, złe przewijanie, wolne obroty, rzadziej zdarza się, że nie nagrywają, jeszcze rzadziej, że w ogóle nie odtwarzają. Kamera przenosi się do sklepu, ekspedient wkłada kasetę do kolejnych magnetofonów, które wyraźnie zniekształcają dźwięk. „Za małe, za małe, wolne obroty” mówi sprzedawca. „Coś tu poza magnetofonem nie gra” - wyrokuje narrator, po czym dodaje, że tym, co szwankuje, jest ,wewnętrzna kontrola produkcji”.

Jednak ekipa PKF nie mogła wciąż ganić zakładów za złą jakość, ponieważ wkrótce okazało się, że ilość wyprodukowanego sprzętu nie jest bez znaczenia. Stabilizacja epoki Gierka okazała się bowiem kolosem na glinianych nogach i wkrótce dało się wyczuć pierwsze oznaki kryzysu. Jak pisze Jerzy Kochanowski:

Społeczeństwo przyzwyczaiło się zarówno do rosnącej i coraz bardziej wyrafinowanej konsumpcji, jak również do stałych cen, które w dużej mierze straciły rolę czynnika wyznaczającego granice popytu. Im bardziej rozbudzone były apetyty konsumpcyjne, tym boleśniej odczuwano każde zachwianie równowagi rynkowej. Znamiona kryzysu były wyraźnie widoczne już w 1974 roku. We wrześniu odnotowano wzrost przychodów społeczeństwa daleko wykraczający ponad założony plan. Za pieniędzmi trafiającymi do kieszeni Polaków nie nadążały dostawy rynkowe. Nawet w dobrze zazwyczaj zaopatrzonej Warszawie zabrakło na przełomie

42 J. Kochanowski, Tylnymi drzwiami. Czarny rynek w Polsce 1944-1989, Wyd. Neriton, Instytut Historyczny UW, Warszawa 2010, s. 89.

43. Co z jakością?, PKF 74/47B, Kronika 1974. 
sierpnia i września 1974 roku m.in. lepszych gatunków mięsa, pralek, lodówek, mebli, sprzętu radiotechnicznego ${ }^{44}$.

W związku z coraz bardziej odczuwalnym kryzysem, rok później ci sami realizatorzy wrócili do hal produkcyjnych, aby opowiedzieć o tym, jak załoga odpowiedziała na apel Gierka i Piotra Jaroszewicza o dodatkową produkcję, deklarując milion egzemplarzy wysokiej jakości magnetofonów i magnetowidów (Milion z Kasprza$k a, 1975)^{45}$. Natomiast kilka miesięcy później Kronika Filmowa zdecydowała się też odwiedzić Zakłady Radiowe Diora, aby opowiedzieć o tragicznej jakości produkcji oraz leniwej załodze, złożonej z samych ,brakorobów” (Radia z Diory, 1976) ${ }^{46}$.

\section{Sen o potędze}

W 1972 roku powstało przedsiębiorstwo państwowe „Pewex”, którego działalność miała charakter tzw. eksportu wewnętrznego, polegającego na tym, że w sieci ekskluzywnych jak na warunki PRL sklepów można było kupić lepszej jakości towary produkcji krajowej oraz zagranicznej, jednak jedynie za twardą walutę, czyli amerykańskiego dolara. Powstanie ,peweksów” miało na celu ściągnięcie przez państwo dewiz, które pozyskiwano dzięki sprzedaży produktów krajowych, co było mimo wszystko łatwiejszym rozwiązaniem niż próba podbicia rynków zagranicznych. Niemniej jednak przewidywana dekadę wcześniej możliwość „ofensywy eksportowej” polskich produktów stała się nagle realną, a wręcz palącą potrzebą ekonomiczną. Sytuacja gospodarcza kraju wpłynęła na politykę przedsiębiorstw produkujących sprzęt elektrotechniczny, które zaczęły rozglądać się za możliwością eksportu własnych wyrobów na rynki Europy Zachodniej oraz na inne kontynenty, gdzie również próbowano sprzedawać je za dewizy.

Od połowy lat 70. Diora zaczęła wysyłać swoich pracowników na targi oraz wystawy sprzętu radiotechnicznego do krajów RWPG, ale znacznie częściej niż do tej pory również do krajów zachodnioeuropejskich oraz np. do krajów afrykańskich (Algieria). Celem tych wyjazdów było ,zebranie materiałów i informacji o sprzęcie radiowym, tendencjach rozwojowych, stylizacji i rozwiązaniach układowych" - jak pisał Norbert Berger w sprawozdaniu z pobytu na targach w Berlinie Zachodnim w sierpniu i wrześniu 1975 roku $^{47}$. Podczas podróży zagranicznych pracownicy Diory zwykle odpowiedzialni byli za obsługę stoiska prezentującego zakłady należące do UNITRY, stąd w ich sprawozdaniach pojawiają się też informacje o tym, któ-

44 J. Kochanowski, Tylnymi drzwiami..., op. cit., s. 87.

45 Milion z Kasprzaka, PKF 75/06B, Kronika 1975.

46 Radia z Diory, op. cit.

47 N. Bergner, Sprawozdanie z pobytu na Funkausstellung $w$ Berlinie Zachodnim od 29 sierpnia do 2 września 1975, Archiwum Państwowe we Wrocławiu / o. Kamieniec Ząbkowicki [APWK], Zakłady Radiowe „Diora” w Dzierżoniowie-596[596]/611, k. 19-23. 
re z wyrobów innych zakładów cieszyły się popularnością wśród zwiedzających i potencjalnych kontrahentów.

Ze względu na użytkowy charakter tej dokumentacji autorzy raportów dość szczerze pisali w nich o swoich spostrzeżeniach, dlatego na ich podstawie można uznać, że doskonale zdawali sobie sprawę z niedomagań i braków produkowanego przez ich zakłady sprzętu. Porównanie wyrobów UNITRY z tymi produkowanymi w krajach za żelazną kurtyną często wypadało na ich korzyść. W sprawozdaniu z pobytu w Bułgarii we wrześniu 1975 roku Kazimierz Falkiewicz pisał: „rynek bardzo ubogi w sprzęty elektrotechniczne. Dominują odbiorniki sieciowe o dużych gabarytach, ciężkie, często szafowe o nienowoczesnej konstrukcji (lampowe) i o nieefektownym wystroju plastycznym. (...) Nie produkuje się tu w ogóle magnetofonów stereofonicznych oraz odbiorników stereo Hi-fi" ${ }^{48}$. W podobnie optymistycznym tonie pisał Leszek Lindner o stoisku UNITRY w Budapeszcie wiosną 1976 roku:

Z prezentowanych wyrobów niezmiennym od lat zainteresowaniem cieszył się magnetofon ZK-246. Również po raz pierwszy wystawiony Amator-Stereo dzięki nowoczesnej sylwetce wzbudzał duże zainteresowanie i dużo pytań dotyczyło terminu wprowadzenia go na rynek węgierski. Z pozostałych wyrobów uwagę zwiedzających zwracała Elizabeth Hi-Fi, słuchawki SN-62, radiotelefony Echo i Trop oraz magnetowid kasetowy ${ }^{49}$.

Zresztą Lindner zauważał, że podobnie jak w Polsce ,zainteresowanie sprzętem wyższej jakości wynika z zaopatrzenia rynku WRL w sprzęt radiowy. Sklepy sprzedające sprzęt radiowy zaopatrzone są w szeroki asortyment odbiorników turystycznych, stołowych mono- i stereofonicznych. Aktualnie część odbiorników turystycznych została nawet przeceniona"50. Jednak konfrontacja z wymaganiami stawianymi przez rynki zachodnie okazywała się najczęściej zimnym prysznicem. W sprawozdaniu z Targów w Lipsku we wrześniu 1975 roku Lindner pisze, że najczęściej zadawano mu pytania o to, ,kiedy pojawią się nowości, ponieważ te same sprzęty prezentowane są od 1973 roku, a zmiany techniczne są zbyt mało eksponowane", oraz czy można się spodziewać, że Diora zacznie produkować zestawy składające się z ,tunera, wzmacniacza, »deków« gramofonowych i magnetofonowych, które można by nabywać oddzielnie i stopniowo kompletować" 51 .

Wydaje się, że parametry techniczne sprzętu produkowanego przez Diorę były zadowalające, ponieważ zakład produkował odbiorniki sprzedawane w Europie Wschodniej, np. przez Teslę (Czechosłowacja) lub Heim Electric (NRD), ale również wypuszczane na rynek zachodni z logiem Thomson-Brandt oraz Continental Edison

48 K. Falkiewicz, Sprawozdanie z delegacji stużbowej do Flovdiv w okresie 20.VIII-15.IX.75 r., APWK 596/611, k. 32-33.

49 L. Lindner, Sprawozdanie z MT Budapeszt, wiosna '76, w dniach 16-30 maja 1976, APWK 596/611, k. 66-67.

50 Ibidem.

51 L. Lindner, Sprawozdanie z wyjazdu stużbowego do NRD na MT w Lipsku - Jesień '75 w okresie 27.08-10.09.75 r., APWK 596/611, k. 34. 
(odbiornik T-166). Jednak podstawowym problemem, z którym przez cały okres lat 70. zmagał się zakład, była ich usterkowość. W przypadku niektórych modeli dochodziła ona do 30\% całej partii (np. odbiorniki „Junior” i „Amor” eksportowane do NRD). Zatem oprócz delegacji, których celem był udział w targach lub festiwalach, inżynierowie nieustannie wysyłani byli do krajów, z którymi Diora miała podpisane umowy handlowe, aby na miejscu naprawiać wadliwy sprzęt. Zimne lutowanie, niedostrojone obwody wejściowe, zwarcia w detektorze, porysowane obudowy lub, jak w przypadku reklamacji dostawy „Elizabeth Hi-Fi” oraz „Amatorów-Stereo” zgłoszonej przez firmę Implex z Kopenhagi, „źle nastrojone dolne częstotliwości zakresu UKF, na skutek czego odbierany był sygnał duńskiej policji” ${ }^{52}$ - to tylko niektóre z pojawiających się ustawicznie usterek. Faktem jest, że proces produkcji oraz kontrola techniczna w firmach zachodnich były już w tym czasie w dużej mierze zautomatyzowane, a polskie zakłady dopiero przymierzały się do wprowadzenia tego typu zmian.

Jeśli przyjrzymy się raportom dotyczącym jakości, to można dojść do wniosku, że większość usterek powstawała na skutek zbyt pośpiesznego montowania lub niestarannego pakowania. Jednocześnie w raportach dotyczących funkcjonowania zakładu mowa jest o tym, że wszystkie straty, jakie poniósł w 1968 roku, wynikały z nieterminowej produkcji oraz usterkowości produkowanego sprzętu, szczególnie tego przeznaczonego na eksport ${ }^{53}$. Mowa jest również o tym, że zakład musiał stworzyć ponad 300 miejsc pracy, szczególnie na stanowiskach monterskich i związanych z kontrolą jakości, aby zminimalizować opóźnienia związane z wdrażaniem nowych projektów na rynek. Postulowano także w kolejnych latach „wprowadzenie i rozszerzenie mechanizacji, automatyzacji oraz wprowadzenie nowych metod technologicznych" 54 , wydaje się więc, że zakład nie był sobie w stanie poradzić z przewidywaną skalą produkcji, bazując jedynie na dotychczasowych metodach pracy. Jednak sytuacja nie uległa raptownej zmianie, ponieważ „Elizabeth Hi-Fi” była jeszcze odbiornikiem montowanym w dużej mierze ręcznie na taśmie.

W sprawozdaniu z pobytu na Festiwalu Dźwięku w Paryżu w marcu 1977 roku Bergner pisał, że choć sprzęt produkowany przez zakłady UNITRY, wystawiony na stoiskach firm zaopatrywanych przez Brandta, nie odbiegał jakością od wyrobów dostarczanych tym firmom przez innych producentów światowych, to szata odbiorników produkcji Diory, m.in. DSH 301, TSH 101 oraz „Elizabeth Hi-Fi”, wypadała blado na ich tle. „Na skutek zastosowania niewłaściwych oklein, źle rozwiązanych skali, rozmieszczenia elementów i niewłaściwych proporcji sprzętu, wyglądał bardzo

52 N. Bergner, Sprawozdanie z wyjazdu stużbowego do firmy Impolex - Kopenhaga, 27.10.-2.11.1975 r., APWK 596/611, k. 40.

53 Por. Konferencje samorzadu robotniczego. Projekt planu na rok 1969/70, Zakłady Radiowe „Diora” w Dzierżoniowie, Dzierżoniów marzec 1969, APWK 596/26.

54 Ibidem. 
nienowocześnie i ubogo" 55 - pisał. W tym czasie obowiązującymi trendami we wzornictwie sprzętu grającego były: wprowadzony przez japońską firmę Sanyo „Military Look" (taśmy parciane do przenoszenia odbiornika na ramieniu), będący jego złagodzoną wersją „styl profesjonalny” oraz „styl europejski”, który „, charakteryzował się nieostrymi, zaokrąglonymi krawędziami”. Wszystkie modele posiadały duże, wyraźne, jasno i równomiernie oświetlone skale, standardem stawały się również zegary elektroniczne ze wskazówkami na digitronach i LED-ach, w związku z czym zegary klapkowe okazywały się niemodnym przeżytkiem. Autorzy wszystkich raportów podkreślali zgodnie, że polskie wzornictwo jest przestarzałe. Czkawką odbijały się więc rozważania Wszoły sprzed zaledwie kilku lat, który twierdził, że nowoczesne odbiorniki należy produkować małymi seriami, a resztę zaprojektować tak, aby przypadły do gustu miłośnikom jeleni na rykowisku i meblościanek na „wysoki połysk”. Teraz potrzebne były nowoczesne wzory odbiorników, w których liczyła się precyzja wykonania każdego detalu, jak również jakość użytych materiałów. W scentralizowanym systemie, w którym zakład zależał od całego łańcucha dostawców i nie mógł liczyć ani na ich rzetelność, ani na systematyczność, ciężko było sprostać tego typu wymaganiom rynku.

W podsumowaniu raportu Bergner pisze, że oprócz uczestnictwa w Festiwalu Dźwięku „dokonał przeglądu zaopatrzenia sprzętu radiowego” w dwóch domach towarowych przy Hôtel de Ville oraz przy bulwarze Haussmanna, a wnioski, jakie wyciąga, są symptomatyczne. Autor raportu odnotowuje bowiem, że w sklepach tych można nabyć sprzęt prezentowany na stoiskach festiwalowych, a jego ceny nie odbiegają od podanych w cennikach. Fakt, że czyni taką uwagę, wiele mówi o kondycji przemysłu radiotechnicznego w Polsce, gdzie produkowało się te same modele w jakości eksportowej oraz pośledniej jakości sprzęt przeznaczony na rynek krajowy.

\section{Zakończenie}

Transformacja ustrojowa i gospodarcza w Polsce sprawiła, że niemalże wszystkie zakłady należące do Zjednoczenia Przemysłu Elektronicznego UNITRA upadły, a przez wiele lat panowało przekonanie, że przyczyną tego stanu rzeczy była zła jakość produkowanych przez nie sprzętów, które nie były w stanie konkurować na wolnym rynku. Kłopoty ZR Diora pojawiły się w latach 80 ., kiedy z powodu zaostrzenia technologicznego embargo trudno było pracownikom działu technologicznego pozyskać komponenty do odbiorników radiowych z firm zachodnich, w związku z czym stały się one mało konkurencyjne wobec sprzętu zachodniego, nie tyle pod względem jakości, ale również ceny oraz designu. Kiedy po transformacji rynek krajowy zalały o wiele gorszej jakości, ale przede wszystkim tańsze sprzęty RTV, Diora próbowała ratować się, rozszerzając swój asortyment np. o odtwarzacze kaset VHS, tunery do

55 N. Bergner, Sprawozdanie z pobytu na XVIII międzynarodowym Festiwalu Dźwięku w Paryżu, 9-13 marca 1976 roku, APWK 596/611, k. 54. 
odbioru telewizji satelitarnej oraz odbiorniki telewizyjne, jednak nadal miała problemy z utrzymaniem się na rynku. W 1989 roku Diora została przekształcona w spółkę akcyjną, jednak jej działalność generowała straty, które w 1995 roku spowodowały utratę płynności finansowej przez firmę, co przełożyło się na brak możliwość kontynuowania produkcji. O zagrożeniach i szansach wynikających z realiów wolnego rynku mówił na antenie Wiadomości TVP ówczesny dyrektor Spółki Akcyjnej Diora SA Eugeniusz Nowak w 1990 roku $^{56}$, natomiast dekadę później jej pracownicy wystąpili dwukrotnie w programie Sprawa dla reportera Elżbiety Jaworowicz, w którym przed kamerą opowiadali o tym, że pomimo doskonałych wyników, jakie osiąga produkowany przez nich sprzęt w niezależnych testach jakościowych, ich zakład umiera. Agencja Rozwoju Przemysłu udzieliła firmie pożyczki celowej na wznowienie produkcji, jednak ostatecznie firma upadła w 2006 roku.

Hasło „Złą produkcję musisz naprawić sam” okazało się jedynie sloganem propagandowym, ponieważ bez nowoczesnych metod produkcji nie było to możliwe. Po transformacji produkty UNITRY stały się bardziej dostępne, jednak ich zakup wciąż stanowił dość dużą inwestycję, w związku z czym Polacy woleli zaoszczędzić, kupując tańszy sprzęt elektroniczny, lub zainwestować w sprzęt zachodnich firm.

Wydaje się, że właśnie owo przekonanie o złej jakości i nienowoczesności produktów wytwarzanych przez Diorę, Kasprzaka, Eltrę, Radmor czy Fonikę przełożyło się na zupełny brak zainteresowania historią zakładów radiotechnicznych i sprzętu elektronicznego produkowanego w PRL. Lekceważące podejście do tego tematu sprawiło, że w momencie zamykania zakładów ich archiwa były wyrzucane na śmietnik, jak w przypadku Foniki lub archiwum Kasprzaka, z którego zachował się jedynie niewielki zespół akt.

Obecnie, prawdopodobnie na fali retro-nostalgii, zainteresowanie tym sprzętem powraca: fani sprzętu wymieniają się częściami i wiedzą fachową oraz organizowane są wystawy, na których prezentowane są „kultowe” sprzęty grające epoki PRL, jednak wciąż brakuje opracowań naukowych na ten temat, przedstawiających historię zakładów UNITRA w kontekście problematyki społecznej, kulturowej oraz ekonomicznej i gospodarczej. Uważam, że jest na tym polu wiele do zrobienia, a przynajmniej niektóre, kultowe sprzęty grające domagają się tak dogłębnych analiz, jakie poświęcone zostały grom na gruncie platform studies $^{57}$.

56 Relacja Wacława Sondeja dla Wiadomości TVP1 ze stycznia 1990 roku, https://www.youtube.com/ watch? $\mathrm{v}=\mathrm{FS} 96 \mathrm{X} 2 \mathrm{YQGa8}$.

57 Zob. książki z serii Platform studies na stronie wydawnictwa MIT: https://mitpress.mit.edu/books/ series/platform-studies. 


\section{Bibliografia}

\section{Archiwa}

Archiwum Akt Nowych w Warszawie [AAN], KC PZPR, XI/775.

Archiwum Państwowe we Wrocławiu/ o. Kamieniec Ząbkowicki [APWK], Zakłady Radiowe „Diora” w Dzierżoniowie - 596.

Ośrodek Dokumentacji i Zbiorów Programowych [ODiZP], Telewizja Polska SA.

Wspomnienia stuchaczy dotyczace historii radia przesłane $w$ związu z ogłoszona $w$ prasie i radiu „Radiowa Ankieta Wspomnień” z okazji 50-lecia PR, Spuścizna Macieja Kwiatkowskiego, Archiwum Polskiego Radia, MK-A/408.

\section{Materiały Polskiej Kroniki Filmowej}

Co z jakościa??, PKF 74/47B, Kronika 1974.

Jeszcze o Targach, PKF 58/25A, Kronika 1958.

Milion z Kasprzaka, PKF 75/06B, Kronika 1975.

Na przykład „Kasprzak”, PKF 65/14B, Kronika 1965.

Przed III Zjazdem - zobowiązania zakładów pracy, PKF 59/03A, Kronika 1959.

Radia z Diory, PKF 76/09B, Kronika, 1976, Polska.

Radioodbiorniki jako nagroda dla chłopów, którzy odstawili świadczenia rzeczowe dla państwa, PKF 46/10, Kronika 1946.

Warszawskie salony, PKF 62/01A, Kronika 1961.

\section{Literatura}

Czy zmierzch radia z gramofonem?, „Diora. Gazeta Samorządu Robotniczego”, 22 lipca 1974.

DIO-RA-DIO. Zakłady Radiowe Unitra „Diora” w Dzierżoniowie, Wydawnictwo Przemysłu Maszynowego „WEMA”, Warszawa 1978.

Dobrzyński K., Człowiek i dźwięk. O kulturze stuchania radia, Warszawa 1973.

Guz L. i in., Bez reklamacji. Ankieta „, Trybuny Ludu” na temat jakości, Warszawa 1966.

Kochanowski J., Tylnymi drzwiami. Czarny rynek w Polsce 1944-1989, Wyd. Neriton, Instytut Historyczny UW, Warszawa 2010.

Mówi dyrektor „Diory” inż. Z. Jędryczka, „Diora. Gazeta Samorządu Robotniczego”, styczeń 1968.

Rynek czeka na „Jubilata-Stereo”, „Diora. Gazeta Samorządu Robotniczego”, 22 lipca 1974.

Ustawa z dn. 3 stycznia 1946 r. o przejęciu na własność Państwa podstawowych gałęzi gospodarki narodowej, Dziennik Ustaw Rzeczpospolitej Polskiej, z 1946 r., nr 3, poz. 17.

Walewska J., Białecki M., Zakłady „IKA” jako przykład nacjonalizacji przemysłu radiotechnicznego po wojnie (z Maciejem Białeckim), w: Hi-tech za żelazna kurtyna. Elektronika, komputery i systemy sterowania w PRL, red. M. Sikora, IPN, Katowice 2017. 
Joanna Walewska

Wszoła T., Wzornictwo - problem zasadniczy, „Diora. Gazeta Samorządu Robotniczego”, listopad 1967.

Wszoła T., Żegnajcie „promyki”, „Diora. Gazeta Samorządu Robotniczego”, styczeń 1968.

Yasuhara Y., The Myth of Free Trade: The Origins of COCOM 1945-1950, „The Japanese Journal of American Studies" 1991, nr 4. 